\title{
Mammal hunting by the Shuar of the Ecuadorian Amazon: is it sustainable?
}

\author{
Galo Za pata - Ríos, Carlos Urgilés and Esteban SuÁrez
}

\begin{abstract}
Although hunting is still critical to the subsistence of many people throughout Amazonia, this practice may not be sustainable under current socio-economic conditions. Native societies are rapidly undergoing socioeconomic changes that exacerbate the pressure on wildlife and habitats, indicating the urgent need to assess the impacts of subsistence hunting. In a 12-month study we assessed hunting patterns in four Shuar native communities in the Ecuadorian Amazon. Hunting patterns and impact of hunting activities were documented using interviews, direct observations, self-monitoring records, community landscape mapping and mammal surveys. Although Shuar harvest a wide-range of wildlife species, including insects, amphibians, reptiles, birds and mammals we only report information about mammals. A total of 3,181 individuals (c. $26,000 \mathrm{~kg}$ ) of 21 mammal species were hunted during the 12 months. We used three algorithms for assessing the sustainability of hunting: the production, stock-recruitment and harvest models. Of the 21 mammal species hunted there were sufficient data to assess 15,12 of which were hunted above maximum sustainable levels within the $243 \mathrm{~km}^{2}$ hunting catchment area. The immediate need to conserve wildlife populations is not obvious to Shuar hunters who still enjoy what they perceive to be an inexhaustible source of wild meat. In this context management of Shuar hunting practices to control harvest levels is complex. The assessment presented here is the first step of what needs to be a long-term wildlife management process.
\end{abstract}

Keywords Amazon, Ecuador, mammals, Shuar, subsistence hunting, sustainability assessment.

\section{Introduction}

lthough subsistence hunting is still a critical survival Astrategy for many forest dwellers throughout Amazonia, for many wildlife species this practice is unsustainable under current social and economic conditions in most Amazonian settings (Redford \& Robinson, 1987; Alvard, 1993; Alvard et al., 1997; Bodmer et al., 1997; Mena et al., 2000; Peres, 2000a; Souza-Mazurek et al., 2000; Zapata-Ríos,

Galo Zapata-Ríos (Corresponding author) and Esteban SuÁRez Wildlife Conservation Society-Ecuador Program, Eloy Alfaro N37-224 y Coremo, Apartado Postal 17-21-168, Quito, Ecuador. E-mail gzapata@wcs.org

Carlos Urgilés Universidad Central del Ecuador, Escuela de Biología y Química, Quito, Ecuador.

Received 24 October 2007. Revision requested 3 December 2007. Accepted 20 May 2008.
2001). Sustainable hunting implies that harvest rates of wildlife populations are at a level that meets the consumption needs of local people without reducing wildlife populations to a level at which they are in danger of local extirpation (Bennett \& Robinson, 2000). In this context, evaluation and monitoring of hunting levels is needed to avoid local extinction of important game species and to ensure the long-term cultural survival of indigenous Amazonians.

The first step towards achieving sustainability of subsistence hunting is to identify and characterize the species most frequently hunted and current extraction rates. To evaluate the balance between production and harvest this characterization needs to be combined with information on carrying capacity of the area and species' biology. A major limitation, however, is the scarcity of the appropriate biological data and the difficulty of collecting this information in the field. This problem has been approached by the development of simple algorithms that do not require detailed biological information on any given species, thus providing coarse estimates of sustainability (Robinson \& Redford, 1991, 1994; Slade et al., 1998; Robinson, 2000; Stephens et al., 2002; Bodmer, 2003; Rowcliffe et al., 2003; Bodmer \& Robinson, 2004). These models, although useful, are not free of flaws and limitations, and they allow the detection of overharvest but not of sustainable hunting (Milner-Gulland \& Akçakaya, 2001).

In the southern Ecuadorian Amazon hunting is an integral part of the subsistence and culture of the Shuar group. Previously known as Jívaros, the Shuar people have lived for several centuries in south-eastern Ecuador on the lower slopes of the Andes and the Amazonian lowlands (Stirling, 1938; Steel, 1999). Until recently the small population size and traditional hunting methods of this indigenous group had little impact on wildlife populations (Harner, 1972; Descola, 1994, 1996). However, like many other areas in the Amazon, the Shuar territory is undergoing rapid socio-economic changes that increase the pressure on wildlife and habitats. Although there have been several anthropological studies of this indigenous group (Karsten, 1935; Stirling, 1938; Ghinassi, 1939; Harner, 1972; Descola, 1994; Taylor \& Landázuri, 1994; Steel, 1999), little is known about their patterns of wildlife use. Here we document Shuar hunting patterns, and assess their impact on large mammals using three sustainability algorithms: the production model (Robinson \& Redford, 1991), the stockrecruitment model and the harvest model (Bodmer, 2003; Bodmer \& Robinson, 2004). 


\section{Study area}

The study site, an area of $600 \mathrm{~km}^{2}$ known as Miasal, is on the western margin of the Amazon basin at altitudes of 2501,200 $\mathrm{m}$, at the foot of the steep Kutukú mountain range in south-eastern Ecuador (Morona-Santiago province). The region, located on the easternmost border of one of the world's biodiversity hotspots (the Tropical Andes), has been recognized for its biodiversity (Mittermeier et al., 1998; Myers et al., 2000). Miasal is defined by the watershed of the Mangosiza river, a white-water river that originates in the highlands of Kutukú (c. 2,500 m) draining the area to the south into the Morona river (Fig. 1). The predominant vegetation types are upland moist tropical forest and pre-montane tropical wet forest (Sierra, 1999). Climate is wet and warm, with an annual precipitation of $4,500 \mathrm{~mm}$ and an average monthly temperature of $24^{\circ} \mathrm{C}$ (Winckell et al., 1997).

The Shuar are historically famous for being fierce warriors and for shrinking the heads of their enemies (Up de Graff, 1923; Steel, 1999). With a population of c. 80,000 people this ethnic group constitutes Amazonian Ecuador's second largest indigenous group (Moya, 1998). In Miasal the population is c. 1,000 people (c. $1.7 \mathrm{~km}^{-2}$ ) living in four communities or centros (the smallest administrative unit of the Shuar Federation). The four centros (Entsakua, Kuamá, Pankints and Tsunki) are located along the Mangosiza river, and were established c. 30 years ago when four Shuar families moved to the area looking for new hunting grounds. The centros are close to each other and function as one community, with La Misión as the main central settlement. La Misión is a Salesian missionary post where a church, high school, small first-aid health centre and several sport fields have been built. People from the four centros gather every weekend at La Misión to socialize and sometimes trade wild meat and agricultural produce.

Miasal is isolated from urban population centres. Depending on water level, it can be reached via the Mangosiza river in $6 \mathrm{~h}$ to 1.5 days from Puerto Morona by motorized canoe. From Macas, the capital city of Morona-Santiago province, it can be reached after a 45 -minute flight in a small plane but the costs are high (c. USD 80 per person). Shuar also use footpaths, one parallel to the river that take 2 days to reach Puerto Morona, and another, to the west, that takes 5 days to reach Macas, crossing the Kutukú mountain range. Although, some ecotourism activities occur in the area, the economy is largely based on subsistence agriculture (plantain and manioc), and a high percentage of protein intake still comes from wild meat, mainly large mammals.

\section{Methods}

This study was carried out from September 2001 to January 2003. During the first 2 months a series of introductory
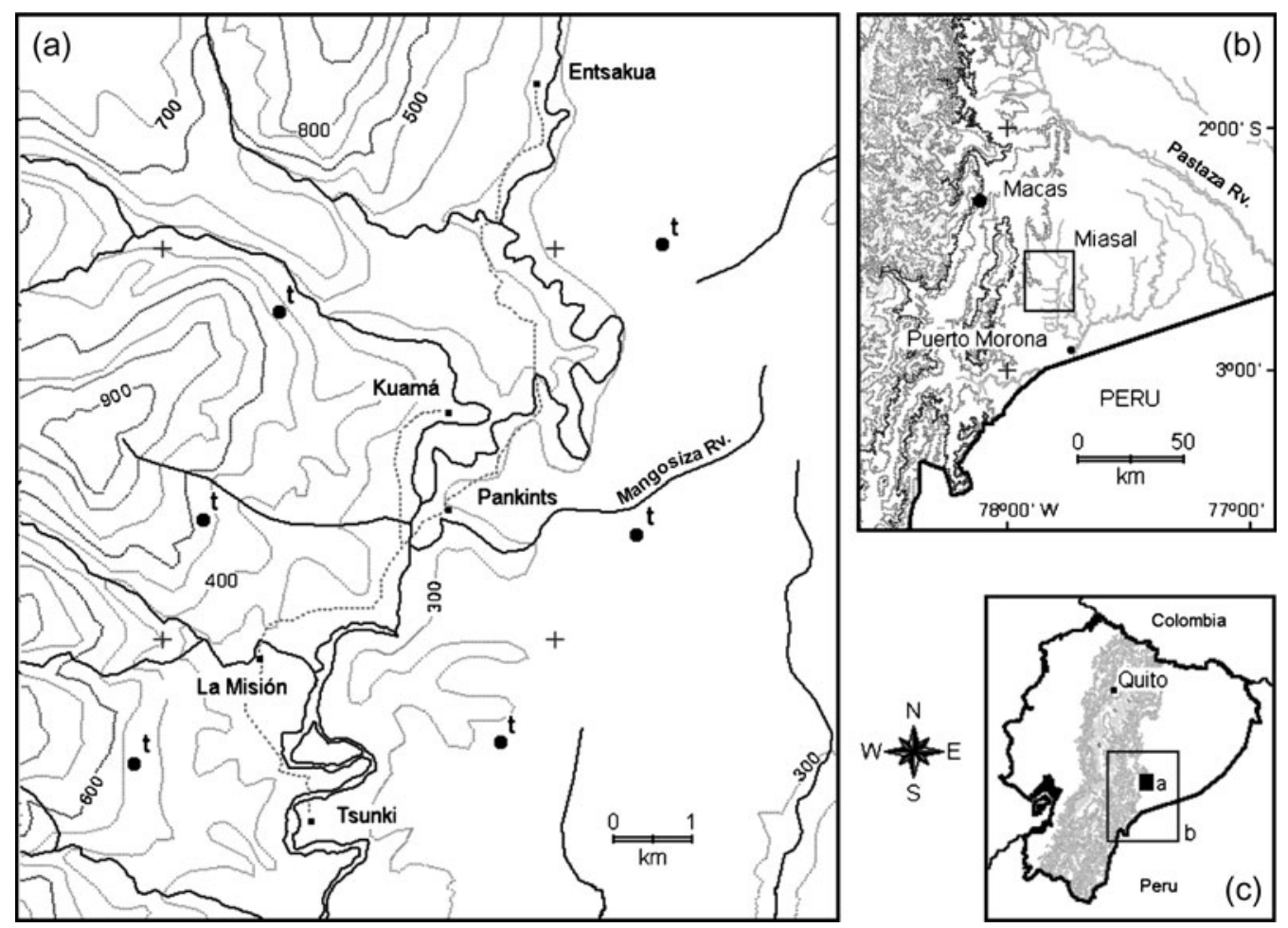

FIG. 1 (a) The study area, Miasal, on the eastern slopes of the Kutukú mountain range, in south-eastern Ecuador, showing the location of the four Shuar communities, La Misión, and the six line transects ( $t$ ), (b) the regional context (Morona-Santiago province), and (c) the location of the province in Ecuador. 
meetings were organized in the four communities to obtain permission to work in the territory of Miasal and to engage the local hunters to participate and support the project. Hunting patterns and impact of hunting activities were documented during 12 complete months using interviews, direct observations, self-monitoring records (Townsend, 1999; Noss et al., 2003, 2004; Zapata-Ríos \& Jorgenson, 2003), participatory mapping (Chapin \& Threlkeld, 2001; Sheil et al., 2002) and mammal surveys (Sutherland, 1996; Wilson et al., 1996; Rabinowitz, 1997). The last 3 months of the study were dedicated to return the research results to the communities, design wildlife management strategies, and sign agreements with the communities for the implementation of wildlife management plans.

An inventory of species harvested in the area was carried out using several techniques. In addition to accompanying hunters for direct observation of hunting techniques and prey harvested, a series of bi-weekly structured interviews were conducted with hunters. Interviews, in Spanish, included questions on species hunted and local names, and characteristics of the prey (sex, age, reproductive status, weight). Respondents were also asked to identify on a map the approximate location where the hunt took place, the vegetation type, the time of the hunting event and weapons used. To involve hunters in this research and to reach the more distant households, we developed a hunter selfmonitoring form (written in both Spanish and Shuar). The self-monitoring forms, a simplified and graphical version of the structured interviews, asked for the same information. The self-monitoring form also included a sketch map for hunters to note the approximate location of the hunt. These forms were presented to the hunters in a series of workshops to ensure the questions were clear and to obtain the input of the participants. Every hunter that agreed to participate received a spring scale for measuring the weight of prey. In addition to completing the forms, hunters were asked to provide skulls, feathers or bones of hunted animals to assess the reliability of the information provided by the self-monitoring and interviews. The data from the interviews and self-monitoring forms were used to estimate actual harvest rates. Data from these sources also allowed us to characterize hunting patterns, estimate the hunting catchment area, and describe hunter preferences.

To estimate the density of prey populations in the catchment area we established six transects of 2,000 m, located on both sides of the Mangosiza river on the hunting grounds of the four Shuar communities (Fig. 1). Each transect was surveyed weekly during 6.00-08.00 and 18.00-20.00. We walked slowly (c. $1 \mathrm{~km} \mathrm{~h}^{-1}$ ), looking for mammals and mammal tracks and signs. Censuses were not conducted on rainy days (Peres, 1999). The species, number of individuals, sighting or radial distance (observer to animal distance) and angle, and distance along the transect were recorded for mammals observed. Population densities were calculated using Hayne's estimator, a robust estimator that relies on radial distance observations (Hayne, 1949; Hayes \& Buckland, 1983; Krebs, 1999). In the case of social species, individual density was estimated by multiplying group density by the average group size. Density estimates and information gathered in the interviews and with the self-monitoring forms were used for estimating the sustainability of hunting with three models (Table 1): the production model (Robinson \& Redford, 1991), the stock-recruitment model and the harvest model (Bodmer, 2003; Bodmer \& Robinson, 2004).

Hunters' preferences were analysed using simple linear regression and $\chi^{2}$ goodness-of-fit tests. A simple linear regression model was used to test whether prey availability predicts species' harvest levels (Rao, 1998), evaluating the null hypothesis that hunters are selecting prey species at random (higher numbers will be extracted of more abundant species). The $\chi^{2}$ goodness-of-fit-test evaluated the null hypothesis of no difference between proportions of use by the hunters and prey availability. In addition, 90\% adjusted Wald confidence intervals $(\hat{w})$ for the expected proportions of use $\left(p_{\exp }\right)$ were calculated for each individual species to determine whether a species is preferred (Agresti \& Coull, 1998; Agresti, 2007). Where the observed proportion ( $\left.p_{\text {obs }}\right)$

TABLE 1 The three sustainability models used to estimate the impact of hunting, and the sources of data.

\begin{tabular}{|c|c|c|c|}
\hline Algorithm & Model & Parameters & Data source \\
\hline $\begin{array}{l}\text { Production model (Robinson \& } \\
\quad \text { Redford, 1991) }\end{array}$ & $\begin{array}{l}P_{\max }=\left(0.6 D \lambda_{\max }\right)-0.6 D, \\
\text { where } \lambda_{\max }=\mathrm{e}^{r}\end{array}$ & $\begin{array}{l}P_{\max }, \text { maximum sustainable production } \\
D \text {, population density } \\
\lambda_{\max }, \text { finite rate of increase } \\
r \text {, intrinsic rate of natural increase }\end{array}$ & $\begin{array}{l}\text { Calculated from data } \\
\text { Line transects } \\
\text { Calculated from } r \\
\text { Robinson \& Redford (1986) }\end{array}$ \\
\hline $\begin{array}{l}\text { Stock-recruitment model } \\
\quad \text { (Bodmer, 2003; Bodmer \& } \\
\text { Robinson, 2004) }\end{array}$ & $d N / d t=r N^{*} 1-(N / K)$ & $\begin{array}{l}N \text {, population density as a } \% \text { of } K \\
r \text {, intrinsic rate of natural increase } \\
K \text {, carrying capacity }\end{array}$ & $\begin{array}{l}\text { Line transects } \\
\text { Robinson \& Redford (1986) } \\
\text { Mena et al. (1997) }\end{array}$ \\
\hline $\begin{array}{l}\text { Harvest model (Bodmer, 2003; } \\
\text { Bodmer \& Robinson, 2004) }\end{array}$ & $P=(0.5 D)(Y g)$ & $\begin{array}{l}P \text {, production } \\
D \text {, density } \\
Y \text {, litter size } \\
g \text {, gestations per year }\end{array}$ & $\begin{array}{l}\text { Calculated from data } \\
\text { Line transects } \\
\text { Interviews, self-monitoring } \\
\text { Eisenberg \& Redford (1999) }\end{array}$ \\
\hline
\end{tabular}


of use did not lie within the interval $\left(p_{\exp } \pm \hat{w}\right)$, differences between expected and observed use of species were identified as significantly different.

The three algorithms require population parameters (Table 1) and current harvest rates. The production and harvest models assess sustainability by comparing actual extraction rates with estimated production thresholds. In the production model (Robinson \& Redford, 1991; Robinson, 2000) we compared the harvest rates $(E)$ for each species obtained from the interviews and self-monitoring forms to the theoretical maximum sustainable harvest $(H)$ estimated using the density data from the line-transects and the intrinsic rate of natural increase (Robinson \& Redford, 1986). In the harvest model we also compared the harvest rates $(E)$ obtained from the interviews and self-monitoring forms to a production estimate based on estimated fecundity rates (litter size and gestations per year) and population densities (Bodmer, 2003; Bodmer \& Robinson, 2004).

The stock-recruitment model (Bodmer, 2003; Bodmer \& Robinson, 2004) does not use an estimate of production as a standard for comparison. It is based on a densitydependent population model that uses maximum sustainable yield (MSY) and an estimate of carrying capacity to assess the status of wildlife populations in hunted areas. The model (Bodmer \& Robinson, 2004) assesses hunting sustainability for different population sizes depending on the distance between population size and carrying capacity $(K)$. Population size (as a percentage of $K$ ) was obtained from the density estimates, and $K$ was assumed to be the population size in unhunted areas. Because obtaining data from unhunted areas was logistically infeasible, these estimates were obtained from the literature (Mena et al., 1997). These density estimates (from the Waorani territory in the Ecuadorian Amazon, $150 \mathrm{~km}$ north of Miasal) were obtained and analysed implementing the same methodology used in this study, in an area with similar ecological characteristics (Sierra, 1999). The combined use of the three models increases the reliability of our assessment of the sustainability of the wildlife harvest.

\section{Results}

The Shuar of Miasal are devoted hunters, using traditional and introduced techniques. Hunting tools include guns, blowguns, sticks, machetes and dogs. There is a short supply of ammunition for guns in the area, and prices are highly variable. When ammunition is scarce Shuar hunters use seeds of the palm Aiphanes schultzeana (Bennett et al., 2002), known as ampakai-kamancha. Seventy-nine percent of all hunting events we recorded involved the use of nontraditional devices, particularly guns. There were no Shuar hunters in the area who remembered how to craft blowguns and prepare the poison for darts (curare). They purchase these items from Achuar traders (indigenous people from the Ecuadorian-Peruvian border) and sometimes use them. The average age of male hunters was 30 years $(n=94$, range 13-54). Women also participate in hunting activities, especially hunting around the house and in the kitchen garden. Because of the community's isolation, commercial hunting does not occur, although a minimum level of trade takes place among members of the communities, providing subsistence level income used for medicines and school supplies for children.

The total sampling effort along the six transects was $384 \mathrm{~km}$. Density estimates were calculated for 15 species that are frequently hunted (Table 2). A total of 401 individuals of the 15 species were recorded, i.e. a sighting rate of 1.04 sightings $\mathrm{km}^{-1}$. Sightings per species ranged from three (lowland tapir Tapirus terrestris) to 134 (green acouchy Myoprocta pratti). These numbers represent a wide range in sampling effort to obtain a detection event $(2.8 \mathrm{~km}$ for $M$. pratti, and $128 \mathrm{~km}$ for $T$. terrestris). The minimum recommended sample size for obtaining robust density estimates of 20 detection events per species (Peres, 1999) was only obtained for six of the 15 species.

In the initial meetings 176 hunters were identified. After an initial effort to accompany Shuar hunters ( 38 trips with 12 hunters) this methodology was discarded as an objective means of gathering hunting data because our presence was affecting the behaviour of the hunters (e.g. showing off their skills with blowguns by aiming at small species such as hummingbirds and cockroaches). Other techniques were more successful. A total of 284 interviews were conducted with 30 hunters on a bi-weekly basis and a total of 2,397 self-monitoring forms were gathered during the 12 months. The self-monitoring forms were completed at least once by 160 hunters ( $91 \%$ of the hunters in the study area), and 119

TABle 2 Density $(D)$ estimates for the 15 species of mammal that were frequently hunted in Miasal.

\begin{tabular}{llr}
\hline Species & $\mathrm{D} \pm \mathrm{SE}\left(\mathrm{km}^{-2}\right)$ & \multicolumn{1}{c}{$\mathrm{n}$} \\
\hline Nine-banded armadillo & $19.31 \pm 7.4$ & 12 \\
$\quad$ Dasypus novemcinctus & & \\
Black agouti Dasyprocta fuliginosa & $13.78 \pm 0.3$ & 46 \\
Kinkajou Potos flavus & $11.10 \pm 1.8$ & 60 \\
Paca Agouti paca & $9.74 \pm 2.4$ & 22 \\
Green acouchy Myoprocta pratti & $8.60 \pm 0.1$ & 134 \\
Spix's owl monkey Aotus vociferans & $8.41 \pm 3.9$ & 27 \\
South American coati Nasua nasua & $7.38 \pm 0.9$ & 15 \\
Red howler monkey Alouatta seniculus & $6.83 \pm 4.3$ & 9 \\
White-fronted capuchin monkey & $5.94 \pm 3.2$ & 8 \\
$\quad$ Cebus albifrons & & \\
Common woolly monkey & $4.78 \pm 2.3$ & 6 \\
$\quad$ Lagothrix lagothricha & & \\
Red brocket deer Mazama americana & $4.67 \pm 0.7$ & 27 \\
Collared peccary Pecari tajacu & $4.29 \pm 2.3$ & 17 \\
Monk saki Pithecia monachus & $3.69 \pm 1.9$ & 9 \\
Lowland tapir Tapirus terrestris & $0.87 \pm 0.6$ & 3 \\
Ocelot Leopardus pardalis & $0.30 \pm 0.2$ & 6 \\
\hline
\end{tabular}


hunters (68\%) periodically reported their activities. A total of 1,989 items such as skulls, bones, feathers, and skins of hunted animals accompanied the self-monitoring forms. These items verified $83 \%$ of the forms. With the consent of the hunters the items that were considered of biological importance were submitted to the Ecuadorian Museum of Natural Sciences in Quito.

Although the Shuar harvest a wide range of species (52), including insects, amphibians, reptiles, birds and mammals (fish were not included in the assessment), we only report information about mammals. Data from interviews and self-monitoring forms demonstrated that medium and large mammals $\left(>_{1} \mathrm{~kg}\right)$ were the preferred prey, comprising $61 \%$ of the total biomass harvested. A total of 3,181 individuals, belonging to 21 mammal species, were hunted during the study, with collared peccary Pecari tajacu $(7,177 \mathrm{~kg})$ being the most important (Table 3). Other important species were red brocket deer Mazama americana, common woolly monkey Lagothrix lagotricha, T. terrestris, paca Agouti paca and nine-banded armadillo Dasypus novemcinctus (Table 3). Based on participatory mapping the hunting catchment area was c. $243 \mathrm{~km}^{2}$ ( $40 \%$ of the total territory of the four communities). A total of 825 hunting events $(26 \%$ of 3,181$)$ ground-truthed using a global positioning system confirmed the map sketches obtained from self-monitoring forms and generated during participatory mapping exercises (Fig. 2). Data from participatory mapping, interviews, and self-monitoring forms also suggest that large-bodied species $(>5 \mathrm{~kg}$ ) have been extirpated (red howler monkey Alouatta seniculus, L. lagotricha and T. terrestris) or have been substantially reduced (M. americana, $P$. tajacu and $A$. paca) within a $3 \mathrm{~km}$ radius of the communities (Fig. 2). Hunters travel $>3 \mathrm{~km}$ from the communities to capture these species.

The goodness-of-fit test $\left(\chi^{2}=71.41, \quad \mathrm{P}<0.0001\right)$ indicates that the proportions of species hunted differed significantly from the proportion of species available (Table 4). The adjusted Wald confidence intervals show that L. lagotricha and P. tajacu were hunted significantly more than expected according to availability (Table 4). The linear regression also suggests that Shuar hunters prefer to hunt large-bodied mammals such as L. lagotricha $(\mathrm{n}=531)$ and P. tajacu $(\mathrm{n}=384)$, which occur in low densities, than more abundant species such as $A$. paca $(\mathrm{n}=351)$ and black agouti Dasyprocta fuliginosa ( $\mathrm{n}=241$; Fig. 3 ).

Of the 21 mammal species hunted 15 had sufficient data to be included in the sustainability assessment. The results of the three algorithms are consistent, and all suggest that only three species are not overhunted (D. novemcinctus, D. fuliginosa and M. pratti; Table 5).

\section{Discussion}

Although line transects have been successfully used to survey mammals in several Neotropical localities (Carrillo et al.,

TABle 3 Total number of individuals ( $\mathrm{n}$ ) and biomass (mean per individual, total and per $\mathrm{km}^{2}$ per year) of 21 species of mammal extracted from the $243 \mathrm{~km}^{2}$ hunting catchment area in November 2001-October 2002.

\begin{tabular}{|c|c|c|c|c|c|}
\hline Species & Shuar name & $\mathrm{n}$ & Mean $\mathrm{kg} \pm \mathrm{SD}(\mathrm{n})^{*}$ & Total kg & $\mathrm{kg} \mathrm{km}^{-2} \mathrm{yr}^{-1}$ \\
\hline Nine-banded armadillo & Shushui & 651 & $4.17 \pm 0.6(121)$ & $2,714.67$ & 11.17 \\
\hline Common woolly monkey & Chuu & 531 & $6.43 \pm 1.4(189)$ & $3,414.33$ & 14.05 \\
\hline Collared peccary & Yankipik & 384 & $18.69 \pm 5.6(103)$ & $7,176.96$ & 29.53 \\
\hline Paca & Kashai & 351 & $7.76 \pm 0.7(89)$ & $2,723.76$ & 11.21 \\
\hline Black agouti & Yunkits & 246 & $3.66 \pm 0.5(156)$ & 900.36 & 3.71 \\
\hline Green acouchy & Shaak & 176 & $0.71 \pm 0.05(67)$ & 124.96 & 0.51 \\
\hline Red brocket deer & Penke japa & 168 & $22.13 \pm 4.6(59)$ & $3,717.84$ & 15.30 \\
\hline Spix's owl monkey & Ujukám & 153 & $0.98 \pm 0.09(61)$ & 149.94 & 0.62 \\
\hline Red howler monkey & Yakump & 140 & $6.56 \pm 1.3(31)$ & 918.4 & 3.78 \\
\hline Monk saki & Sepur & 113 & $2.54 \pm 0.8(75)$ & 287.02 & 1.18 \\
\hline Kinkajou & Kuji & 111 & $2.48 \pm 0.6(37)$ & 275.28 & 1.13 \\
\hline White-fronted capuchin monkey & Tsere & 59 & $2.45 \pm 0.7(22)$ & 144.55 & 0.59 \\
\hline South American coati & Kuink kushi & 35 & $3.47 \pm 1.1(7)$ & 121.45 & 0.50 \\
\hline Ocelot & Yanankam & 34 & 8.94 & 303.96 & 1.25 \\
\hline Lowland tapir & Piuk Pama & 21 & 136.94 & $2,875.74$ & 11.83 \\
\hline Northern Amazon red squirrel Sciurus igniventris & Kunam & 3 & $0.57 \pm 0.03(2)$ & 1.71 & 0.01 \\
\hline Tayra Eira barbara & Amish & 1 & 3.25 & 3.25 & 0.01 \\
\hline Spectacled bear Tremarctos ornatus & Chai & 1 & 81.22 & 81.22 & 0.33 \\
\hline Jaguar Panthera onca & Yampinkia & 1 & 68.2 & 68.2 & 0.28 \\
\hline Crab-eating raccoon Procyon cancrivorus & Papash & 1 & 2.89 & 2.89 & 0.01 \\
\hline Capybara Hydrochaeris hydrochaeris & Unkumia & 1 & 29.88 & 29.88 & 0.12 \\
\hline Total & & 3,181 & & $26,036.37$ & \\
\hline
\end{tabular}

${ }^{*}$ Weights reported were obtained from hunted prey recorded in the field, except for T. ornatus, L. pardalis, P. onca and T. terrestris, data for which were obtained from Seymour (1989), Padilla \& Dowler (1994), Murray \& Gardner (1997), Eisenberg \& Redford (1999) and Tirira (2007) 


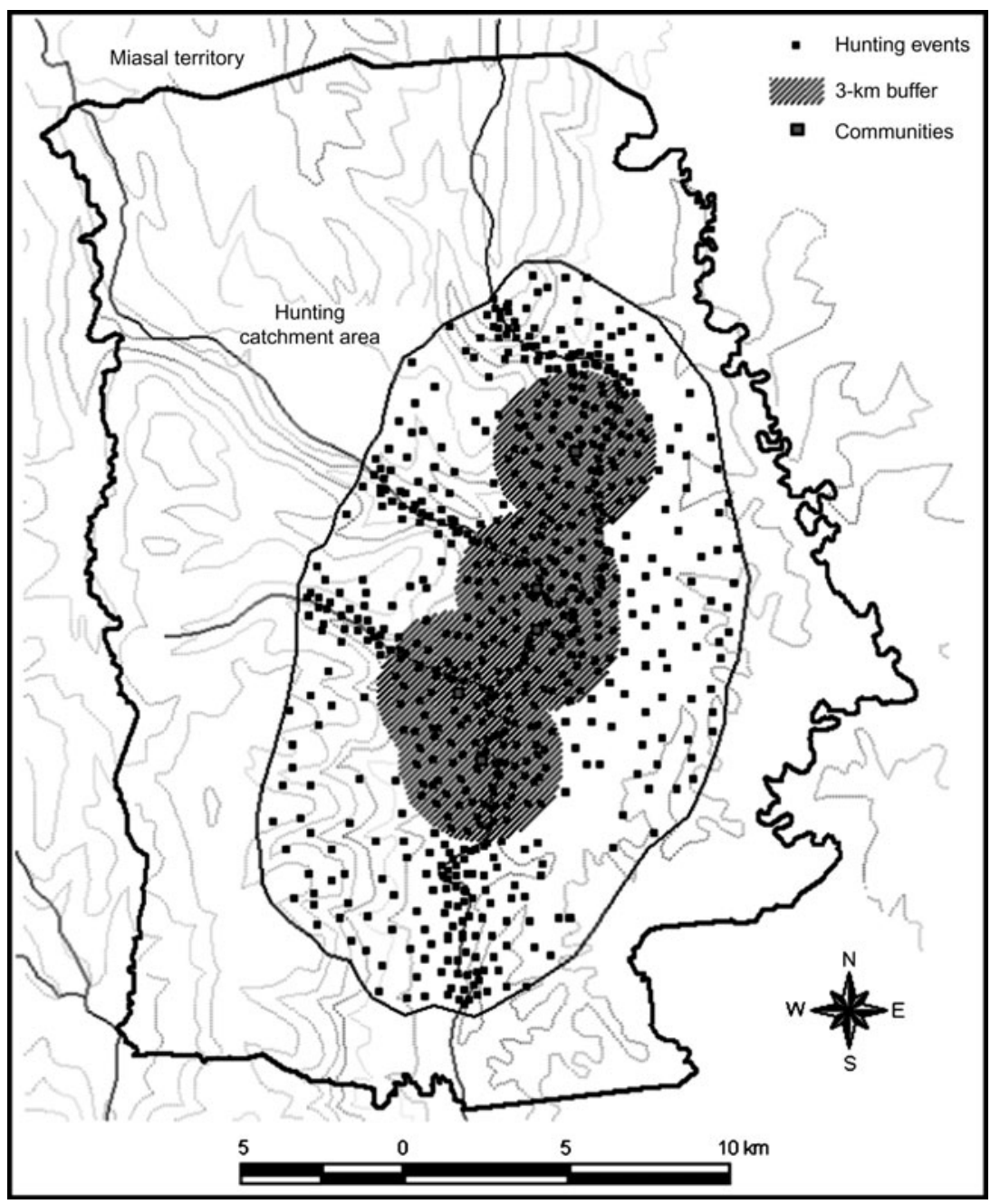

FIG. 2 Miasal (Fig. 1) showing the hunting catchment area $\left(243 \mathrm{~km}^{2} ; 40 \%\right.$ of the total territory of the four communities). The black symbols indicate the location of the 825 hunting events that were groundtruthed with a global positioning system. An area surrounding the communities (within a $3 \mathrm{~km}$ radius) where several large-bodied species have been extirpated or become rare is shown (see text for details).
2000; Peres, 200ob; Cullen et al., 2004) the technique is not free of limitations. The major shortcoming is that large sample sizes are required to apply the estimation models. Recommended sample sizes are 20-80 sightings (Peres, 1999; Buckland et al., 2001). In many tropical forest localities, however, to obtain this number of detection events requires a sampling effort of hundreds or even thousands of $\mathrm{km}$ (Peres, 1999; Carrillo et al., 2000). Although we only obtained the minimum recommended sample size of 20 for six of the 15 species our density estimates lie within the same range as in other hunted Neotropical areas (Hill \& Padwe, 2000; Mena et al., 2000; Peres, 200ob; Cullen et al., 2004).

Shuar hunting as practised today in Miasal is not sustainable. Extraction levels of $80 \%$ of large mammals (12 species out of 15 included in the sustainability assessment) are well above sustainable harvest levels. The main reason for overharvesting of these species is the change of traditional hunting practices and their replacement with more effective hunting methods in the context of the rapid socio-economic changes that have increased demand and depleted wildlife populations (Bennett \& Robinson, 2000; Robinson \& Bennett, 2004). For example, human population growth in the study area (from four to $>100$ families in the last 30 years) has caused an unprecedented demand that has increased hunting pressure (INEC, 2002). Human population density is high (Robinson \& Bennett, 2000) for a population that depends on wildlife for its major source of protein (c. 4.1 people $\mathrm{km}^{-2}$ in the hunting catchment area, c. 1.7 people $\mathrm{km}^{-2}$ for the total area of the communities). As expected, our results (Table 5) confirm that mammal species with higher intrinsic rates of natural increase $(r)$, higher densities $(\mathrm{N})$, and higher fecundity rates ( $Y$ and $g$ ) are more resilient to hunting pressure than those species with lower levels of the same parameters (Bodmer \& Robinson, 2004). Under these circumstances, unless urgent wildlife management strategies are implemented (e.g. hunting quotas, hunting rotations, access to alternative protein sources, and changes in consumer behaviour), some species will probably go locally extinct in the near future.

Shuar hunters show preferences for large-bodied species according to optimal foraging principles (Emlen, 1966; MacArthur \& Pianka, 1966), valuing different species based on their body mass-to-capture cost ratio, thus maximizing hunting benefits in terms of economy, energy and time 
TABLE 4 Preferences of Shuar hunters (for the 15 species of mammal of which $>3$ individuals were hunted) analysed using a $\chi^{2}$ goodness-of-fit test and $90 \%$ adjusted Wald confidence intervals $(\hat{w})$ for the expected proportions of use $\left(p_{\exp }\right)$ of prey species. Where the observed proportions of use $\left(p_{\text {obs }}\right)$ do not lie within the interval $p_{\exp } \pm \hat{w}$, differences between expected and observed use of species are considered significantly different (in bold).

\begin{tabular}{|c|c|c|c|c|c|c|}
\hline Species & $\chi^{2}$ & $p_{\text {obs }}$ & $p_{\exp }$ & $\hat{w}$ & $p_{\exp }-\hat{\mathrm{w}}$ & $\mathrm{p}_{\exp }+\hat{\mathrm{w}}$ \\
\hline Nine-banded armadillo & 0.482 & 0.205 & 0.176 & 0.144 & 0.032 & 0.320 \\
\hline Common woolly monkey & 35.155 & 0.167 & 0.044 & 0.077 & 0.000 & 0.121 \\
\hline Collared peccary & 17.155 & 0.121 & 0.039 & 0.073 & 0.000 & 0.112 \\
\hline Paca & 0.536 & 0.111 & 0.089 & 0.107 & 0.000 & 0.196 \\
\hline Black agouti & 1.841 & 0.078 & 0.126 & 0.125 & 0.001 & 0.251 \\
\hline Green acouchy & 0.671 & 0.055 & 0.078 & 0.101 & 0.000 & 0.180 \\
\hline Red brocket deer & 0.253 & 0.053 & 0.043 & 0.076 & 0.000 & 0.119 \\
\hline Spix's owl monkey & 1.056 & 0.048 & 0.077 & 0.100 & 0.000 & 0.177 \\
\hline Red howler monkey & 0.529 & 0.044 & 0.062 & 0.091 & 0.000 & 0.153 \\
\hline Monk saki & 0.012 & 0.036 & 0.034 & 0.068 & 0.000 & 0.102 \\
\hline Kinkajou & 4.332 & 0.035 & 0.101 & 0.114 & 0.000 & 0.215 \\
\hline White-fronted capuchin monkey & 2.335 & 0.019 & 0.054 & 0.085 & 0.000 & 0.140 \\
\hline South American coati & 4.703 & 0.011 & 0.067 & 0.095 & 0.000 & 0.162 \\
\hline Ocelot & 2.329 & 0.011 & 0.003 & 0.020 & 0.000 & 0.022 \\
\hline Lowland tapir & 0.022 & 0.007 & 0.008 & 0.033 & 0.000 & 0.041 \\
\hline$\chi^{2}$ & 71.410 & & & & & \\
\hline $\mathrm{P}$ & $<0.0001$ & & & & & \\
\hline
\end{tabular}

allocated (Bodmer, 1995; Fitzgibbon et al., 2000; Jerozolimski \& Peres, 2003; Hilaluddin et al., 2004). In the study area, however, large-bodied species ( $>5 \mathrm{~kg}$ ) such as $A$. seniculus, L. lagotricha, T. terrestris, M. americana, P. tajacu, and A. paca have been depleted in the immediate vicinity of the four communities, and hunters travel $>3 \mathrm{~km}$ to find them. Shuar hunters, therefore, are reaching a threshold where they will no longer be able to be selective. Local depletion in the areas that surround the four communities (Fig. 2) may explain why the Shuar are exploiting a range of medium- and small-sized species (Fig. 3) to obtain higher returns from hunting activities, a common response to overhunting (Mena et al., 2000; Jerozolimski \& Peres, 2003). This phenomenon has reached its extreme in other areas of Ecuador where small rodents and marsupials (e.g. Proechimys semispinosus, Oryzomys spp. and Didelphis marsupialis) are the main source of protein for local communities (Suárez et al., 1995). Biological and ecological differences between species (population density, life span, reproductive rates) render some more susceptible to overharvesting than others (Bodmer, 1995; Bodmer et al., 1997). Large primates (e.g. A. seniculus, L. lagotricha, Ateles belzebuth), tapirs and other largebodied species are more vulnerable to the negative impacts of hunting than small-bodied species such as acouchies (M. pratti), agouties (D. fuliginosa) and armadillos (D.novemcinctus; Table 5).

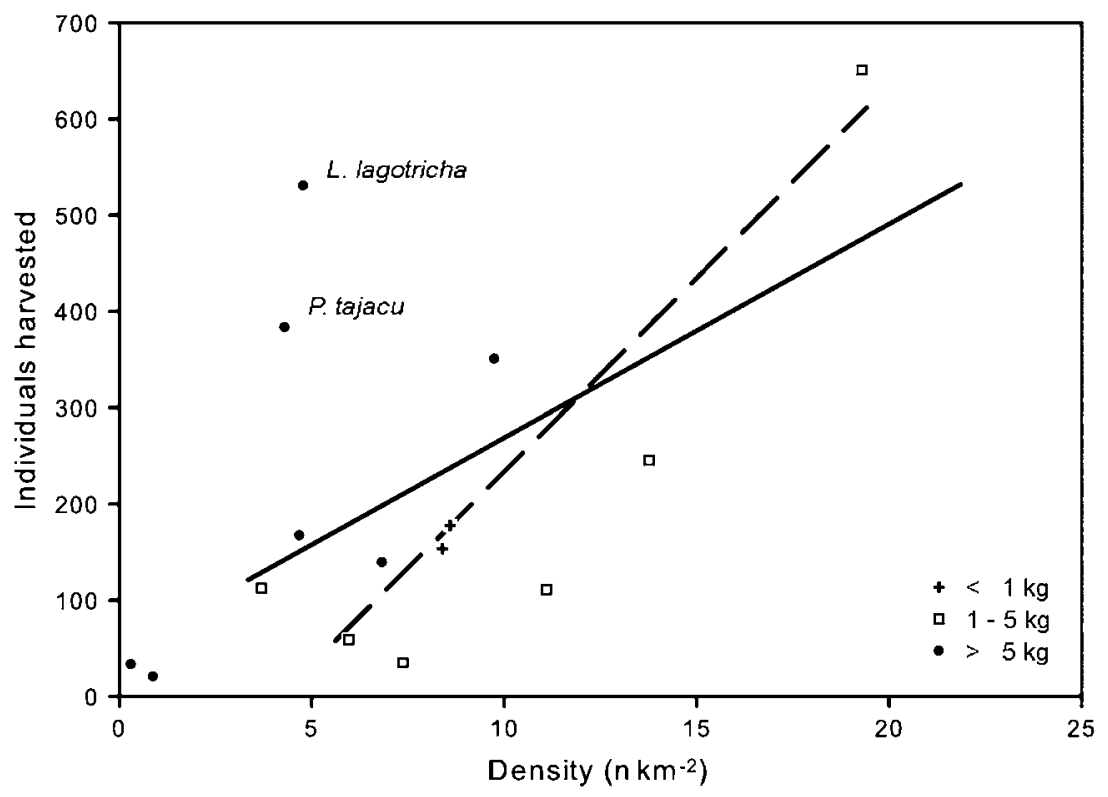

FIG. 3 Numbers of 15 species of prey most commonly hunted versus their density (Table 2 ), and linear regressions for all species (solid line, $\left.r^{2}=30.68 \%, \mathrm{P}=0.03\right)$ and excluding the two outliers (Lagothrix lagotricha and Pecari tajacu; dashed line, $r^{2}=68.38 \%, \mathrm{P}$ $=0.0007)$. The regressions suggest that prey species are not hunted according to their availability (see text for details). 


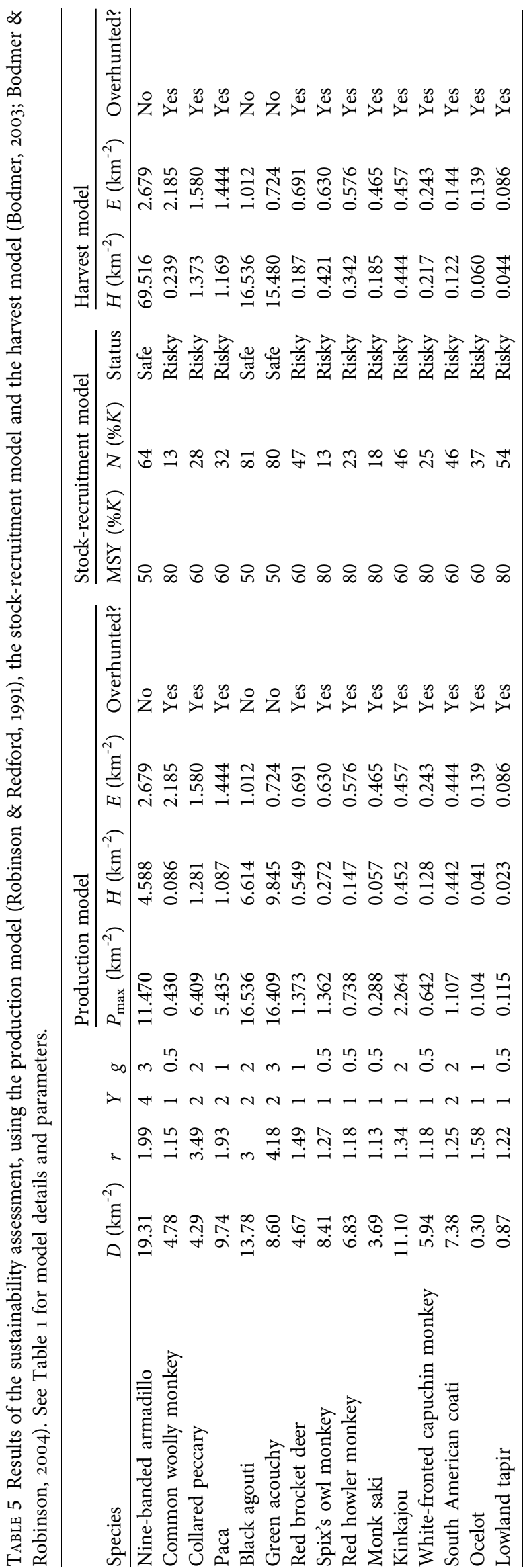

The hunting assessment presented here represents only 12 months of a dynamic and ongoing process of wildlife extraction. Sustainability indices cannot show that a harvest is sustainable, only that it is unsustainable. Therefore, we cannot be sure that the three species (D. novemcinctus, $D$. fuliginosa and $M$. pratti) whose extraction levels suggest they are not currently overhunted will continue to be so in the long-term. The hunting grounds of the communities $\left(243 \mathrm{~km}^{2}\right)$ are surrounded by a larger area $\left(\mathrm{c} .350 \mathrm{~km}^{2}\right)$ that is part of the legal territory of the communities. This larger territory may still be an important wildlife source area, which could explain why overhunted species have not yet been extirpated within the catchment area after several decades of harvesting (Joshi \& Gadgil, 1991; Novaro et al., 2000). Anthropogenic pressures are increasing as surrounding communities are starting to use this source area as their hunting grounds. Current patterns of wildlife exploitation can only be expected to intensify with current rates of population growth throughout Shuar territory (c. 6.5\% per year; unpubl. data of the Shuar Federation, 2004). Research elsewhere in the Neotropics also reports that current patterns of wildlife use are unsustainable (Peres, 2000b; Naughton-Treves et al., 2003; Altrichter, 2005; de Thoisy et al., 2005; Franzen, 2006). This regional pattern is going to cause local and regional extinctions of preferred species and people will no longer be able to obtain a sufficient protein supply from hunting. Ultimately, the impact of this overhunting will have negative ecological and socioeconomic repercussions.

Although many Shuar hunters recognize that protein sources from wildlife populations are steadily diminishing, the immediate need to conserve wildlife populations to ensure its future availability is not obvious to hunters who still enjoy what they perceive to be an inexhaustible source of meat. In this context, management of Shuar hunting practices to control harvest levels is complex. Support for this project was obtained because the Shuar were interested in developing a locally-managed ecotourism operation and were worried about the decline of wildlife species in the areas surrounding their communities, areas that are frequented by the tourists that visit the area. The results of these analyses were presented to the communities on several occasions during and at the end of the study. After a series of eight 1-day participatory meetings the four communities signed, in January 2003, an agreement for the implementation of a series of wildlife management strategies. During these meetings the communities discussed pragmatic strategies, including establishing hunting zones, prohibiting hunting by outsiders, implementing offtake quotas (by sex, age and season), and prohibiting hunting of highly vulnerable species such as T. terrestris.

Since the agreement was signed the members of the four Shuar communities have been implementing the wildlife 
management strategies and a wildlife monitoring programme with limited external support. Periodical patrols of their territory have lowered, but not eliminated, hunting by outsiders. The majority of the hunters are actively involved in this community-based initiative and comply with the community regulations, although some continue to overharvest wildlife species and are under strong social pressure to stop this practice. However, several internal conflicts unrelated to hunting are currently threatening the long-term implementation of the wildlife management plan. This community-owned process is still promising but the results need to be consolidated to guarantee the longterm sustainability of hunting by the Shuar of these four communities.

\section{Acknowledgements}

Funding was provided by USAID through CARE International's Program of Sustainability and Regional Union. We are grateful to Ecuador's Ministry of the Environment for granting permission to undertake this study (026-IC-FAU/ DBAP/MA). The Shuar Federation granted permission for working in Shuar territory. The Shuar community of Miasal (Entsakua, Kuamá, Pankints and Tsunki) provided great support and hospitality throughout the study. It is impossible here to name all of the Shuar hunters who assisted in the field but we extend our warm thanks to all of them. We are greatly indebted to Juan Carlos Jintiach and Patricia Arcos and her family for their continuous logistical support. The effort of the Arcos family to conserve their territory is meritorious and remarkable. Servicio Aéreo Misional provided us safe and reliable transportation by small plane to Miasal. Juan Francisco Rivadeneira of the Ecuadorian Museum of Natural Sciences received and catalogued the specimens provided by the Shuar hunters. Edison Araguillin carried out most of the mammal surveys and Carlos Morales helped gather hunting data. Víctor Utreras, Karen Kainer, Brian Child and Ari Martinez provided useful comments on earlier drafts, and the insightful comments of David S. Wilkie and two anonymous reviewers greatly improved this manuscript.

\section{References}

Agresti, A. (2007) An Introduction to Categorical Data Analysis. John Wiley \& Sons, Hoboken, USA.

Agresti, A. \& Coull, B.A. (1998) Approximate is better than 'exact' for interval estimation of binomial proportions. The American Statistician, 52, 119-126.

Altrichter, M. (2005) The sustainability of subsistence hunting of peccaries in the Argentine Chaco. Biological Conservation, 126, 351-362.

Alvard, M.S. (1993) Testing the 'Ecologically Noble Savage' hypothesis: interspecific prey choice by Piro hunters of Amazonian Peru. Human Ecology, 21, 355-387.
Alvard, M.S., Robinson, J.G., Redford, K.H. \& Kaplan, H. (1997) The sustainability of subsistence hunting in the Neotropics. Conservation Biology, 11, 977-982.

Bennett, B.C., Baker, M.A. \& Gómez, P. (2002) Ethnobotany of the Shuar of Eastern Ecuador. New York Botanical Garden Press, New York, USA.

Bennett, E.L. \& Robinson, J.G. (2000) Hunting for sustainability: the start of a synthesis. In Hunting for Sustainability in Tropical Forests (eds J.G. Robinson \& E.L. Bennett), pp. 499-519. Columbia University Press, New York, USA.

Bodmer, R.E. (1995) Managing Amazonian wildlife: biological correlates of game choice by detribalized hunters. Ecological Applications, 5, 872-877.

Bodmer, R.E (2003) Evaluación de la sustentabilidad de la caza en los Neotrópicos: el modelo de cosecha unificado. In Manejo de Fauna Silvestre en Amazonía y Latinoamérica (ed. R. Polanco-Ochoa), pp. 252-262. CITES-Fundación Natura, Bogotá, Colombia.

Bodmer, R.E., Eisenberg, J.F. \& Redford, K.H. (1997) Hunting and the likelihood of extinction of Amazonian mammals. Conservation Biology, 11, 460-466.

BODMER, R.E. \& RoBinson, J.G. (2004) Evaluating the sustainability of hunting in the Neotropics. In People in Nature: Wildlife Conservation in South and Central America (eds K.M. Silvius, R.E. Bodmer \& J.M.V. Fragoso), pp. 299-323. Columbia University Press, New York, USA.

Buckland, S.T., Anderson, D.R., Burnham, K.P., Laake, J.L., Borchers, D.L. \& Thomas, L. (2001) Introduction to Distance Sampling: Estimating Abundance of Biological Populations. Oxford University Press, Oxford, UK.

Carrillo, E., Wong, G. \& Cuarón, A.D. (2000) Monitoring mammal populations in Costa Rican protected areas under different hunting restrictions. Conservation Biology, 14, 1580-1591.

Chapin, M. \& Threlkeld, B. (2001) Indigenous Landscapes: A Study in Ethnocartography. Center for the Support of Native Lands, Arlington, USA.

Cullen, L., Jr, Bodmer, R.E., Valladares-Pádua, C. \& Ballou, J.D. (2004) Mammalian densities and species extinctions in Atlantic forest fragments: the need for population management. In People in Nature: Wildlife Conservation in South and Central America (eds K.M. Silvius, R.E. Bodmer \& J.M.V. Fragoso), pp. 211-226. Columbia University Press, New York, USA.

De Thoisy, B., Renoux, F. \& Julliot, C. (2005) Hunting in northern French Guiana and its impact on primate communities. Oryx, 39, 149-157.

Descola, P. (1994) In the Society of Nature: A Native Ecology in Amazonia. Cambridge University Press, Cambridge, UK.

Descola, P. (1996) La Selva Culta: Simbolismo y Praxis en la Ecología de los Achuar. Ediciones Abya-Yala, Quito, Ecuador.

EisenberG, J.F. \& RedFord, K.H. (1999) Mammals of the Neotropics: The Central Neotropics. University of Chicago Press, Chicago, USA.

EMLEN, J.M. (1966) The role of time and energy in food preference. The American Naturalist, 100, 611-617.

Fitzgibbon, C.D., Mogaka, H. \& Fanshawe, J.H. (2000) Threatened mammals, subsistence harvesting, and high human population densities: a recipe for disaster. In Hunting for Sustainability in Tropical Forests (eds J.G. Robinson \& E.L. Bennett), pp. 154-167. Columbia University Press, New York, USA.

FrANZEN, M. (2006) Evaluating the sustainability of hunting: a comparison of harvest profiles across three Huaorani communities. Environmental Conservation, 33, 36-45.

Ghinassi, J. (1939) Gramática Teórico - Práctica y Vocabulario de la Lengua Jíbara. Talleres Gráficos de Educación, Quito, Ecuador. 
Harner, M. (1972) The Jivaro: People of the Sacred Waterfalls Natural History Press, Washington, DC, USA.

Hayes, R.J. \& BuCKLAND, S.T. (1983) Radial-distance models for the line-transect method. Biometrics, 39, 29-42.

Hayne, D.W. (1949) An examination of the strip census method for estimating animal populations. Journal of Wildlife Management, $13,145^{-157}$.

Hilaludin, R.K., Jandrotia, J.S. \& McGowan, P.J.K. (2004) Hunting of large mammals and pheasants in the Indian western Himalaya. Oryx, 38, 426-431.

Hill, K. \& Padwe, J. (2000) Sustainability of Aché hunting in the Mbaracayu Reserve, Paraguay. In Hunting for Sustainability in Tropical Forests (eds J.G. Robinson \& E.L. Bennett), pp. 79-105. Columbia University Press, New York, USA.

ineC (Instituto Nacional de Estadísticas y Censos del Ecuador) (2002) Evolución de la Población Urbana y Rural, 1950-2001 (Cantón Taisha, Provincia de Morona-Santiago). In VI Censo de Población y V de Vivienda (ed. INEC), pp. 1354-1378. INEC, Quito, Ecuador.

Jerozolimski, A. \& Peres, C.A. (2003) Bringing home the biggest bacon: a cross site analysis of the structure of hunter-kill profiles in Neotropical forests. Biological Conservation, 111, $415-425$.

Joshi, N.V. \& GADGIL, M. (1991) On the role of refugia in promoting prudent use of biological resources. Theoretical Population Biology, 40, 211-229.

Karsten, R. (1935) The Head Hunters of Western Amazon: The Life and Culture of the Jibaro Indians of Eastern Ecuador and Peru. Societas Scientiarum Fennica, Helsinki, Finland.

Krebs, C.J. (1999) Ecological Methodology. Addison-Wesley, New York, USA.

MacArthur, R.H. \& Pianka, E.R. (1966) On optimal use of a patchy environment. The American Naturalist, 100, 603-609.

Mena, P., Regalado, J. \& Cueva, R. (1997) Oferta de animales en el bosque y cacería en la comunidad Huaorani de Quehueiri-ono, zona de amortiguamiento del Parque Nacional Yasuní, Napo, Ecuador. In Estudios Biológicos para la Conservación: Diversidad, Ecología y Etnobiología (eds P. Mena, A. Soldi, R. Alarcón, C. Chiriboga \& L. Suárez), pp. 395-426. EcoCiencia, Quito, Ecuador.

Mena, P., Stallings, J.R., Regalado, J. \& Cueva, R. (2000) The sustainability of current hunting practices by the Huaorani. In Hunting for Sustainability in Tropical Forests (eds J.G. Robinson \& E.L. Bennett), pp. 57-78. Columbia University Press, New York, USA.

Milner-Gulland, E.J. \& Aкçakaya, H.R. (2001) Sustainability indices for exploited populations. Trends in Ecology and Evolution, 16, 686-692.

Mittermeier, R.A., Myers, N., Thomsen, J.B., Da Fonseca, G.A.B. \& OlivieRI, S. (1998) Biodiversity hotspots and major tropical wilderness areas: approaches to setting conservation priorities. Conservation Biology, 12, 516-520.

Moy A, A. (1998) Ethnos: Atlas Etnográfico del Ecuador. Ediciones Abya-Yala, Quito, Ecuador.

Murray, J.L. \& Gardner, G.L. (1997) Leopardus pardalis (Linnaeus, 1758). Mammalian Species, 548, 1-10.

Myers, N., Mittermeier, R.A., Mittermeier, C.G., Da Fonseca, G.A.B. \& Kent, J. (2000) Biodiversity hotspots for conservation priorities. Nature, 403, 853-858.

Naughton-Treves, L., Mena, J.L., Treves, A., Alvarez, N. \& RADeloff, V.C. (2003) Wildlife survival beyond park boundaries: the impact of slash-and-burn agriculture and hunting on mammals in Tambopata, Peru. Conservation Biology, 17, 1106-1117.
Noss, A.J., Cuéllar, E. \& Cuéllar, R.L. (2003) Hunter selfmonitoring as a basis for biological research: data from the Bolivian Chaco. Mastozoología Neotropical, 10, 49-67.

Noss, A.J., Cuéllar, E. \& Cuéllar, R.L. (2004) An evaluation of hunter self-monitoring in the Bolivian Chaco. Human Ecology, 32, 685-702.

Novaro, A.J., Redford, K.H. \& Bodmer, R.E. (2000) Effect of hunting in source-sink systems in the Neotropics. Conservation Biology, 14, 713-721.

Padilla, M. \& Dowler, R.C. (1994) Tapirus terrestris (Linnaeus, 1758). Mammalian Species, 481, 1-8.

Peres, C.A. (1999) Generalized guidelines for standardizing linetransect surveys of tropical forest primates. Neotropical Primates, 7, 11-16.

Peres, C.A. (2000a) Effects of subsistence hunting on vertebrate community structure in Amazonian forests. Conservation Biology, $14,240-253$.

Peres, C.A. (200ob) Evaluating the impact and sustainability of subsistence hunting at multiple Amazonian forest sites. In Hunting for Sustainability in Tropical Forests (eds J.G. Robinson \& E.L. Bennett), pp. 31-56. Columbia University Press, New York, USA.

Rabinowitz, A. (1997) Wildlife Field Research and Conservation Training Manual. Wildlife Conservation Society, New York, USA.

Ra , P.V. (1998) Statistical Research Methods in the Life Sciences. Duxbury Press, Pacific Grove, USA.

ReDFord, K.H. \& Robinson, J.G. (1987) The game of choice: patterns of indian and colonist hunting in the Neotropics. American Anthropologist, 89, 650-667.

Robinson, J.G. (2000) Calculating maximum sustainable harvests and percentage offtakes. In Hunting for Sustainability in Tropical Forests (eds J.G. Robinson \& E.L. Bennett), pp. 521-524. Columbia University Press, New York, USA.

Robinson, J.G. \& BennetT, E.L. (200o) Carrying capacity limits to sustainable hunting in tropical forests. In Hunting for Sustainability in Tropical Forests (eds J.G. Robinson \& E.L. Bennett), pp. 13-30. Columbia University Press, New York, USA.

Robinson, J.G. \& Bennett, E.L. (2004) Having your wildlife and eating it too: an analysis of hunting sustainability across tropical ecosystems. Animal Conservation, 7, 397-408.

Robinson, J.G. \& REDFORD, K.H. (1986) Intrinsic rate of natural increase in Neotropical forest mammals: relationship to phylogeny and diet. Oecologia, 68, 516-520.

Robinson, J.G. \& Redford, K.H. (1991) Sustainable harvest of Neotropical forest mammals. In Neotropical Wildlife Use and Conservation (eds J.G. Robinson \& K.H. Redford), pp. 415-429. The University of Chicago Press, Chicago, USA.

Robinson, J.G. \& Redford, K.H. (1994) Measuring the sustainability of hunting in tropical forests. Oryx, 28, 249-256.

Rowcliffe, J.M., Cowlishaw, G. \& Long, J. (2003) A model of human hunting impacts in multi-prey communities. Journal of Applied Ecology, 40, 872-889.

Seymour, K.L. (1989) Panthera onca (Linnaeus, 1758). Mammalian Species, 340, 1-9.

Sheil, D., Puri, R.K., Basuki, I., van Heist, M., Rukmiyati, S., SARdjono, M.A. et al. (2002) Exploring Biological Diversity, Environment, and Local People's Perspectives in Forest Landscapes: Methods for a Multidisciplinary Landscape Assessment. Center for International Forestry Research, Jakarta, Indonesia.

Sierra, R. (ed.) (1999) Propuesta Preliminar de un Sistema de Clasificación de Vegetación para el Ecuador Continental. INEFAN-EcoCiencia, Quito, Ecuador.

Slade, N.A., Gomulkievicz, R. \& Alexander, H.M. (1998) Alternatives to Robinson and Redford's method of assessing 
overharvest from incomplete demographic data. Conservation Biology, 12, 148-155.

Souza-Mazurek, R.R., Pedrinho, T., Feliciano, X., Hilário, W., Gerôncio, S. \& Marcelo, E. (2000) Subsistence hunting among the Waimiri Atroari indians in central Amazonia, Brazil. Biodiversity and Conservation, 9, 579-596.

Steel, D. (1999) Trade goods and Jivaro warfare: the Shuar 1850-1957, and the Achuar 1940-1978. Ethnohistory, 46, 745-776.

Stephens, P.A., Frey-Roos, F., Arnold, W. \& Sutherland, W.J. (2002) Sustainable exploitation of social species: a test and comparison of models. Journal of Applied Ecology, 39, 629-642.

S TIRLING, M.W. (1938) Historical and Ethnographical Material on the Jivaro. Smithsonian Institution Bureau of American Ethnology, Washington, DC, USA.

Suárez, E., Stallings, J. \& Suárez, L. (1995) Small-mammal hunting by two ethnic groups in northwestern Ecuador. Oryx, $29,35-42$.

Sutherland, W.J. (1996) Ecological Census Techniques: A Handbook. Cambridge University Press, Cambridge, UK.

Taylor, A. \& Landázuri, C. (1994) Conquista de la Región Jívaro (1550-1650). Ediciones Abya-Yala, Quito, Ecuador.

Tirira, D. (2007) Mamíferos del Ecuador: Guía de Campo. Ediciones Murciélago Blanco, Quito, Ecuador.

Townsend, W.R. (1999) Algunas técnicas para ampliar la participación en el manejo de fauna silvestre con comunidades rurales. In Manejo y Conservación de Fauna Silvestre en América Latina (eds T.G. Fang, O.L. Montenegro \& R.E. Bodmer), pp. 141-145. Museo de Historia Natural Noel Kempff Mercado, La Paz, Bolivia.

Up de Graff, F.W. (1923) Head Hunters of the Amazon: Seven Years of Exploration and Adventure (1804-1901). Garden City Publishing Co., New York, USA.

Wilson, D.E., Cole, F.R., Nichols, J.D., Rudran, R. \& Foster, M.S. (1996) Measuring and Monitoring Biological Diversity: Standard Methods for Mammals. Smithsonian Institution Press, Washington, DC, USA.
Winckell, A., Zebrowski, C. \& Sourdat, M. (1997) Las Regiones $y$ Paisajes del Ecuador. ORSTOM-Instituto Geográfico Militar, Quito, Ecuador.

Zapata-Ríos, G. (2001) Sustentabilidad de la cacería de subsistencia: el caso de cuatro comunidades Quichuas en la Amazonía nororiental ecuatoriana. Mastozoología Neotropical, 8, 59-66.

Zapata-Ríos, G. \& Jorgenson, J.P. (2003) La utilización del autoregistro en los estudios de cacería de subsistencia: el ejemplo de los Shuar del suroriente del Ecuador. In Fauna Socializada: Tendencias en el Manejo Participativo de la Fauna en América Latina (eds C. Campos-Rozo \& A. Ulloa), pp. 131-143. Fundación Natura-MacArthur Foundation-Instituto Colombiano de Antropología e Historia, Bogotá, Colombia.

\section{Biographical sketches}

Galo ZaPATA-Ríos's interests include the ecology and conservation of Neotropical mammals, in particular the effects of human activities on wildlife and issues concerning development, deforestation, hunting and human-wildlife conflict. He is currently studying the ecology and distribution of carnivores in the human-dominated landscapes of the Ecuadorian Andes. Carlos URGILÉs's interests include mammalogy and wildlife management. He is currently working in a community-based wildlife management programme in the Ecuadorian Amazon, implemented by the Instituto para la Conservación y Capacitación Ambiental, a local NGO. Esteban SUÁREZ started his career working with Afroecuadorian and Chachi indigenous groups in north-western Ecuador, where he worked with local hunters characterizing their use of small mammals as food. He has also worked with campesino communities in the cloud forests of north-western Ecuador where, in addition to research activities, he collaborated with the local communities in several management and conservation education activities. 